\title{
Utilizing the solar thermal ice storage system in improving the energy, exergy, economic and environmental assessment of conventional air conditioning system
}

Mohamed Elhelw

Alexandria University

Wael M. El-Maghlany ( $\sim$ elmaghlany@alexu.edu.eg )

Alexandria University https://orcid.org/0000-0002-1315-0054

Mohamed Shawky Ismail

Alexandria University

\section{Research Article}

Keywords: Air conditioning, Solar energy, Power saving, Ice thermal storage, Exergy analysis

Posted Date: April 21st, 2021

DOl: https://doi.org/10.21203/rs.3.rs-381124/v1

License: (c) (i) This work is licensed under a Creative Commons Attribution 4.0 International License.

Read Full License 


\title{
Utilizing the solar thermal ice storage system in improving the energy, exergy, economic and environmental assessment of conventional air conditioning system
}

\author{
Mohamed Elhelw, Wael M. El-Maghlany*, Mohamed Shawky Ismail \\ Department of Mechanical Engineering, Faculty of Engineering Alexandria University, \\ Alexandria, Egypt
}

Corresponding author: elmaghlany@alexu.edu.eg;elmaghlany@yahoo.com

\begin{abstract}
This paper introduces novel modification for conventional air conditioning systems through utilizing a thermal ice storage system integrated with solar panels. Alexandria and Aswan, cities in Egypt, are chosen to represent two climates for hot-humid and hot-dry climates respectively. The governing equations for both heat and mass transfer are theoretically solved. Exergy analysis is performed for the proposed solar-ice thermal storage system via determining exergy destruction on ice and solar components as well as the total destruction based on transient analysis. This study was carried out on two common types of air conditioning systems, an air handling unit and fan coil unit. Results showed that, solar-ice storage system is more effective approach in hot-humid climate than hot-dry climate and more efficient with all-water air conditioning system than with all-air conditioning system. The maximum energy saving is 205.16 GJ having a percent of $27.5 \%$ in August for all water system in case of Alexandria city and 224.67 GJ with a percent of $25.38 \%$ in August for all-water system in case of Aswan city. All air system simulation showed maximum energy saving of 175.05 GJ with a percent of $18.13 \%$ in case of August for Alexandria and 175.45 GJ having a percentage of $17.43 \%$ in case of Aswan in August. Moreover, the all-water system achieved a reduction in $\mathrm{CO}_{2}$ emissions by 467 tons/year in Aswan city and 390 tons/year in case of Alexandria city. While these reductions decrease to be 435 and 353 tons/year when the all-air system used for the same two cities.
\end{abstract}

Keywords: Air conditioning; Solar energy; Power saving; Ice thermal storage; Exergy analysis 


\section{NOMENCLATURE}

$\begin{array}{ll}\mathrm{A} & \text { Solar photo-voltaic area }\left(\mathrm{m}^{2}\right) \\ \mathrm{C}_{\mathrm{v}} & \text { Specific heat at constant volume }(\mathrm{kJ} / \mathrm{kg} \mathrm{K}) \\ \mathrm{h} & \text { Enthalpy }(\mathrm{kJ} / \mathrm{kg}) \\ \mathrm{I} & \text { AC electric current }(\mathrm{A}) \\ \mathrm{I}_{\mathrm{ap}} & \text { Solar irradiance value }\left(\mathrm{W} / \mathrm{m}^{2}\right) \\ \mathrm{Igr}_{\mathrm{gr}} & \text { Ground reflected irradiance }\left(\mathrm{W} / \mathrm{m}^{2}\right) \\ \mathrm{I}_{\mathrm{m}} & \text { Current at maximum power, }(\mathrm{Amper}) \\ \mathrm{m} & \text { Mass }(\mathrm{kg}) \\ \mathrm{m}^{\mathrm{o}} & \text { Mass flow rate }(\mathrm{kg} / \mathrm{s}) \\ \mathrm{P} & \text { Electric power }\left(\mathrm{W} / \mathrm{m}^{2}\right) \\ \mathrm{Q} & \text { Heat transfer rate } \\ \mathrm{s} & \text { Entropy }(\mathrm{kJ} / \mathrm{kg} \mathrm{K}) \\ \mathrm{T} & \text { Temperature }(\mathrm{K}) \\ \mathrm{t} & \text { Time }(\mathrm{s}) \\ \mathrm{U} & \text { Overall heat transfer coefficient }\left(\mathrm{kW} / \mathrm{m}^{2} / \mathrm{K}\right) \\ \mathrm{u}_{\mathrm{i}, \mathrm{f}} & \text { Latent heat of fusion }(\mathrm{kJ} / \mathrm{kg}) \\ \mathrm{V} \mathrm{m} & \text { Voltage at maximum power }(\mathrm{V}) \\ \mathrm{v} & \end{array}$

\section{Greek symbols}

$\alpha_{\mathrm{i}} \quad$ Fixed solar panel incidence angle (degree)

$\beta \quad$ Surface tilt angle (degree)

$\gamma \quad$ Surface azimuth angle (degree)

$\gamma_{\mathrm{s}} \quad$ Solar azimuth angle (degree)

$\gamma_{\mathrm{t}} \quad$ Temperature coefficient $\left(1 /{ }^{\circ} \mathrm{C}\right)$

$\delta \quad$ Stefan Boltzman constant

$\varepsilon \quad$ Panel emissivity 
$\eta_{\text {inverter }} \mathrm{DC}$ to $\mathrm{AC}$ inverter efficiency

$\theta_{\mathrm{s}} \quad$ Solar zenith angle (degree)

\section{Subscripts/Abbreviation}

\begin{tabular}{ll} 
AC & Alternative current \\
C & Photo-voltaic cell \\
Comp & Compressor \\
Cond & Condenser \\
COP & Coefficient of operation \\
DC & Direct current \\
ex & Exit \\
Exp & Expansion valve \\
HE & Heat exchanger \\
i & Ice \\
in & In \\
O & Ambient \\
$r$ & Photo-voltaic reference \\
R & Refrigerant \\
sk & Sky \\
w & Water \\
\hline
\end{tabular}

\section{Introduction}

Raising energy efficiency has become top priority for the majority of countries. Climates characterized by relatively higher temperatures require higher magnitudes of electric energy for air conditioning at noon-time periods. The concern about future energy shortage rises as energy consumption levels rise. In 2015, United Nations presented recommendations that assert the necessity of improving the energy efficiency contributes to energy security, better environment and quality of life. Accordingly, there is a great thrust for implementing new solutions and technologies to save energy. One solution is shifting electricity loads to periods considered off- 
peak using a thermal storage technique. Another approach is to implement solar energy for generating electricity to operate various air conditioning systems. Although the two different techniques have been studied before, merging the two approaches as proposed in this research has never been studied or applied on the hot humid and hot dry climates together. The classification of cold storage technologies includes sensible thermal storage technologies (such as chilled water storage) and latent thermal energy storage technologies (such as ice storage) (Shaibani et al. 2019; Talukdar et al. 2019).

\section{Literature Review}

Using ice storage systems or solar energy to minimize the electric energy consumption has been the focus of many researchers in recent years. The fatty acids were studied including stearic, palmitic, lauric, and capric acids, and their binary mixtures' thermal properties which are effective in designing latent thermal storage systems (Feldman and Shapiro 1989). Another research developed a theoretical model considering thermal analysis of an ice storage system utilized with air conditioning systems (Chen et al. 1997). Rosen and Dincer (2003) thermodynamic considerations concerning the design process of thermal energy storage systems. Exergy analysis for a thermal storage system has been carried out by Rosen et al. (2004) to investigate the effect of temperature profile change in exergy storage capacity. Fertelli et al. (2009) studied the effect of changing refrigerant's inlet temperature on the formation of ice around a horizontal tube using an experimental approach. Lin (2014) introduced two new air conditioning systems that utilized chilled energy storage reaching up to $40 \%$ power cost saving. Rohde et al. (2018) analysed a solar-heating and cooling system in Oslo, Norway. They found that increasing the number of solar collectors is a better solution for decreasing the system COP as a result of decreasing the long-term thermal storage temperature. Jack and Wrobel (2009) used an analytical one-dimensional model to perform exergy analysis for a single-medium stratified thermal energy storage device. Their study showed that the stratification lowered the thermo- dynamically optimum time of charging and raised the overall system's efficiency. Sanaye (2013) utilized a genetic algorithm optimization technique to optimize the ice energy storage design parameters reaching lower amounts of energy consumption. Elhelw and Elhefni (2018) proposed a new air conditioning system integrated with solar panels and analysed the system's performance for hot and humid climates. Han et al. (2009) investigated the various types of thermal stratification tanks commonly used in a cold storage tank. They also introduced 
a stratified water tank design that overcomes the common efficiency and energy storage problems. Xu et al. (2017) studied an ice storage air conditioning system driven by solar energy. The results showed that the studied storage system can operate the air conditioning system for 4 hours during night period. Yongfeng et al. (2018) had experimentally tested and compared two operational modes for ice storage system integrated with PV panels, one as the energy stored as ice and the another the energy stored in battery. It had been found that storage the solar energy in ice forming is more efficient than in battery bank. Habeebullah (2006) performed economic analysis for an ice storage system operating as part of the air conditioning plant of the Grand Holy Mosque in Makkah, Saudi Arabia. The results show estimated money savings having the value of $549.4 \$ / \mathrm{d}$ in case of full-load storage and that the total cost of an ice storage system will be recovered in 10 years, and achieving daily cost estimated by 4011.76 \$/day. Li et al. (2015) reduced the peak load on the electrical grid in hot summer climatic zones by utilizing a solar photo-voltaic air conditioning system where the COP (coefficient of performance) for the studied system was estimated around 0.3. Yuehong et al. (2019) thermodynamically analyzed a new $\mathrm{LiBr}-\mathrm{H}_{2} \mathrm{O}$ three-phase energy storage system by using MATLAB. The results showed that energy storage efficiency depend on $\mathrm{LiBr}-\mathrm{H}_{2} \mathrm{O}$ concentration and flow rates. Fang et al. (2005) studied dual-mode refrigeration system for air conditioning utilizing ice storage technologies where they've developed a computational model for the exergy analysis of each component. MacPhee and Dincer (2009) analysed the performance of four different ice storage techniques based on the First and Second Law of thermodynamics. They proved that the total energy efficiency for full storage is a little higher than the total energy efficiency for partial storage. Rismanchi et al. (2012) investigated using load levelling strategy for an ice thermal storage system instead of using conventional air conditioning systems. This new strategy resulted in $4 \%$ reduction of the total energy usage. XiaoXia and Dong (2015) researched performance of an ice storage system using the support vector machine method (SVM) combined with the rough set method (RS) as a new approach for the load prediction. Abo-Elfadl et al. (2021) experimentally examined the newly designed solar air heater. Rismanchi et al. (2012) researched five different thermal energy storage systems for a case study of an office building located in Malaysia. The study outcomes showed that the ice on coil had the maximum exergy efficiency with an amount of $18 \%$. Song et al. (2018) studied three different control schemes (optimizing priority, storage priority and chiller priority) to investigate their effect on energy consumption and operation 
cost. The outcomes proved that the electric price ratio had a notable effect on the control priority. Carbonell et al. (2018) experimentally study four capillary mat heat exchangers in solar-ice storage system. The results show that tube spacing and volume flow rates have a big influence in melting process. Sehar et al. (2012) simulated a non-storage and ice storage chiller for various climatic zones using the Demand Response Quick Assessment Tool. Their study showed that the usage of a storage system is more feasible in dry/cold climates than in humid/cold climates. Abo-Elfadl et al. (2021) studied five different condenser design of solar still. Their results showed that PHS condenser is the best system in reducing $\mathrm{CO}_{2}$ emission.

The novelty of this research is that it evaluates the use of a proposed system combining a thermal storage system utilized with solar panel with the conventional air conditioning system for hot humid and hot dry climates. The other objective is performing transient exergy analysis as well as defining the components of highest exergy destruction within the solar-ice thermal storage system. This study was carried out on two common types of air conditioning systems. The first one consists of an air handling unit (AHU), while the second one includes a fan coil unit (FCU). The final objective is to study the environmental effect of using the proposal systems in hot-dry and hot- humid climate.

\section{Method}

Understanding the need to reduce the consumption of electric energy during peak times was the first step in this study. The second step was to identify the desired goal and to understand the different methods in which this goal could be achieved. Then, the proposed solar-ice storage system was applied on two different air conditioning systems to reduce their energy consumption. A comparison was made between the new proposed system and the old conventional system by using the simulation software; EnergyPlus. Then, exergy calculations were applied on these systems to specify the amount of exergy destruction in each of the system's components. Two buildings were studied for two different weather conditions cases. The weather data of Alexandria and Aswan cities, Egypt are used in this research to express the hot humid and hot dry climates. The maximum and minimum monthly outside temperature and humidity variation during a year for the two cities are presented in Table 1. While, Table 2 presents the average monthly solar radiation for the two studied cities. The desired space conditions for both buildings are $23^{\circ} \mathrm{C}$ dry bulb temperature and $50 \%$ relative humidity. 
Table 1: Outdoor air conditions ranges for studied cities

\begin{tabular}{lcccc}
\hline & \multicolumn{2}{c}{ Temperature $\left[{ }^{\circ} \mathrm{C}\right]$} & \multicolumn{2}{c}{ Moisture content $\left[\mathrm{g}_{\text {water }} / \mathrm{g}_{\text {air }}\right]$} \\
\hline & $\max$ & $\min$ & $\max$ & $\operatorname{Min}$ \\
\hline Alexandria & 35 & 7 & 21.31 & 4.41 \\
Aswan & 45 & 4 & 8.95 & 2.66 \\
\hline
\end{tabular}

Table 2: Monthly average direct solar radiation for Alexandria and Aswan.

\begin{tabular}{lcccccccccccc}
\hline \multicolumn{10}{c}{ Monthly average direct solar radiation $\left(\mathbf{W} / \mathbf{m}^{2}\right)$} \\
\hline & Jan & Feb & Mar & Apr & May & Jun & Jul & Aug & Sept & Oct & Nov & Dec \\
\hline Alexandria & 195 & 209 & 296 & 365 & 442 & 467 & 498 & 444 & 399 & 324 & 257 & 205 \\
\hline Aswan & 406 & 480 & 489 & 540 & 529 & 555 & 537 & 534 & 510 & 456 & 409 & 386 \\
\hline
\end{tabular}

This study focuses on modification of two different conventional systems used for air conditioning, all-water system and all-air system. These two systems are operated in two different cities located in Egypt, Alexandria, and Aswan. These two cities are chosen to represent hot humid and hot dry climates. The all-water air conditioning system includes five $140 \mathrm{~kW}$ cooling capacity chillers. The refrigerant used is R410A. The system utilizes five parallel feed water pumps supplying a mass flow rate of $33.44 \mathrm{~kg} / \mathrm{sec}$. The unit has seventy-five fan coil units as shown in Fig.1-a. While Fig.1b illustrated the all-air air conditioning cycle which consists of ten R22 packaged air handling units, each with an air flow rate of $12500 \mathrm{~m}^{3} / \mathrm{hr}, 70 \mathrm{~kW}$ cooling capacity and $20 \%$ fresh air.

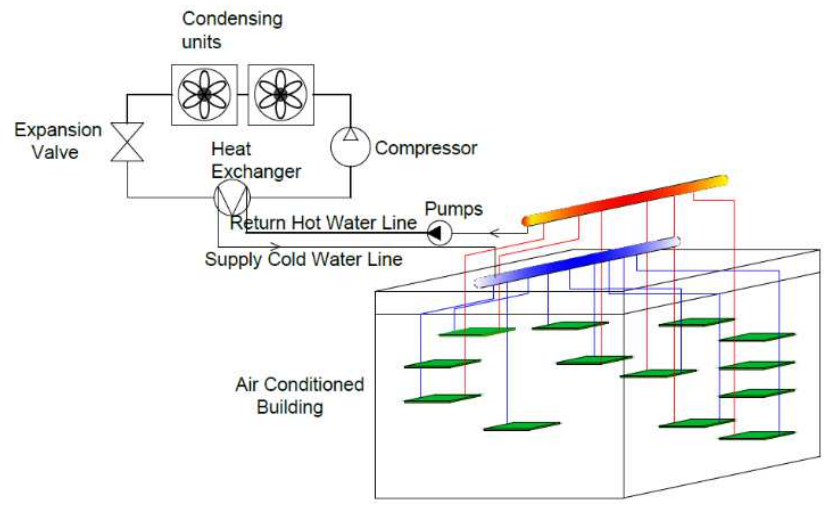

a) All-water air conditioning cycle

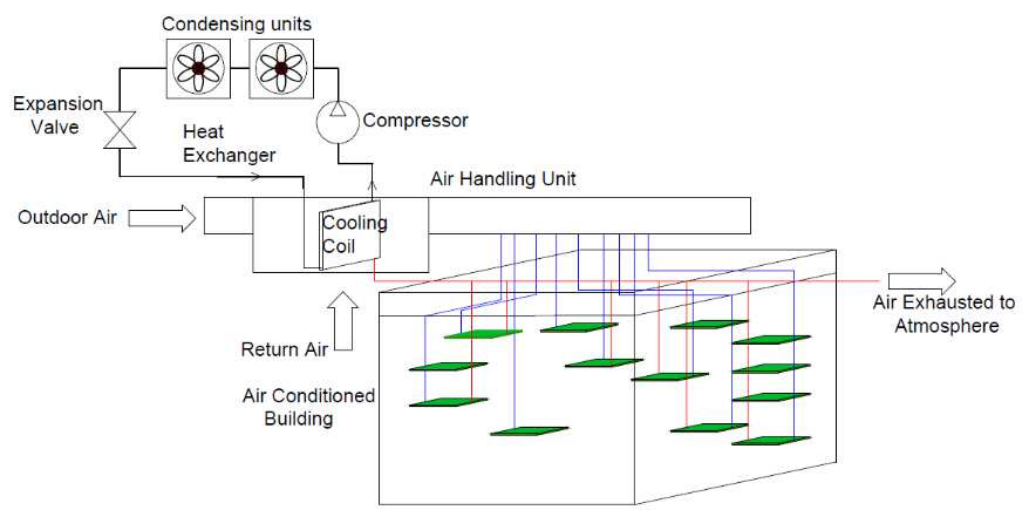

b) All-air air conditioning cycle

Fig. 1. Conventional air conditioning cycles.

The novel solar-ice storage systems presenting the all-water and all-air system types, shown in Fig. 2 , consist of a tank designed at the peak load for storing ice (1). A refrigeration cycle to produce the 
ice (2) which operates at night time to make use of lower outdoor temperatures for achieving higher efficiency as well as making the electrical loads shift to off-peak periods. Chilled water is supplied using a feed water pump to exchange heat with air/water through the heat exchanger (4). In order to control the operation of the studied air conditioning system, the system has four water valves and four water dampers (5) in case of the ice storage cycle in peak periods or by the existing cycle (6) at off peak periods. A set of solar still (7) units which its generated electricity is supplied to the national electricity network to provide continuous electricity to the two proposed system throughout the year through a DC to AC inverter. The electrical feed water pump runs during the electrical peak demand periods consuming negligible amounts of electric energy if compared to the magnitude of electric energy consumed for the operation of compressors.

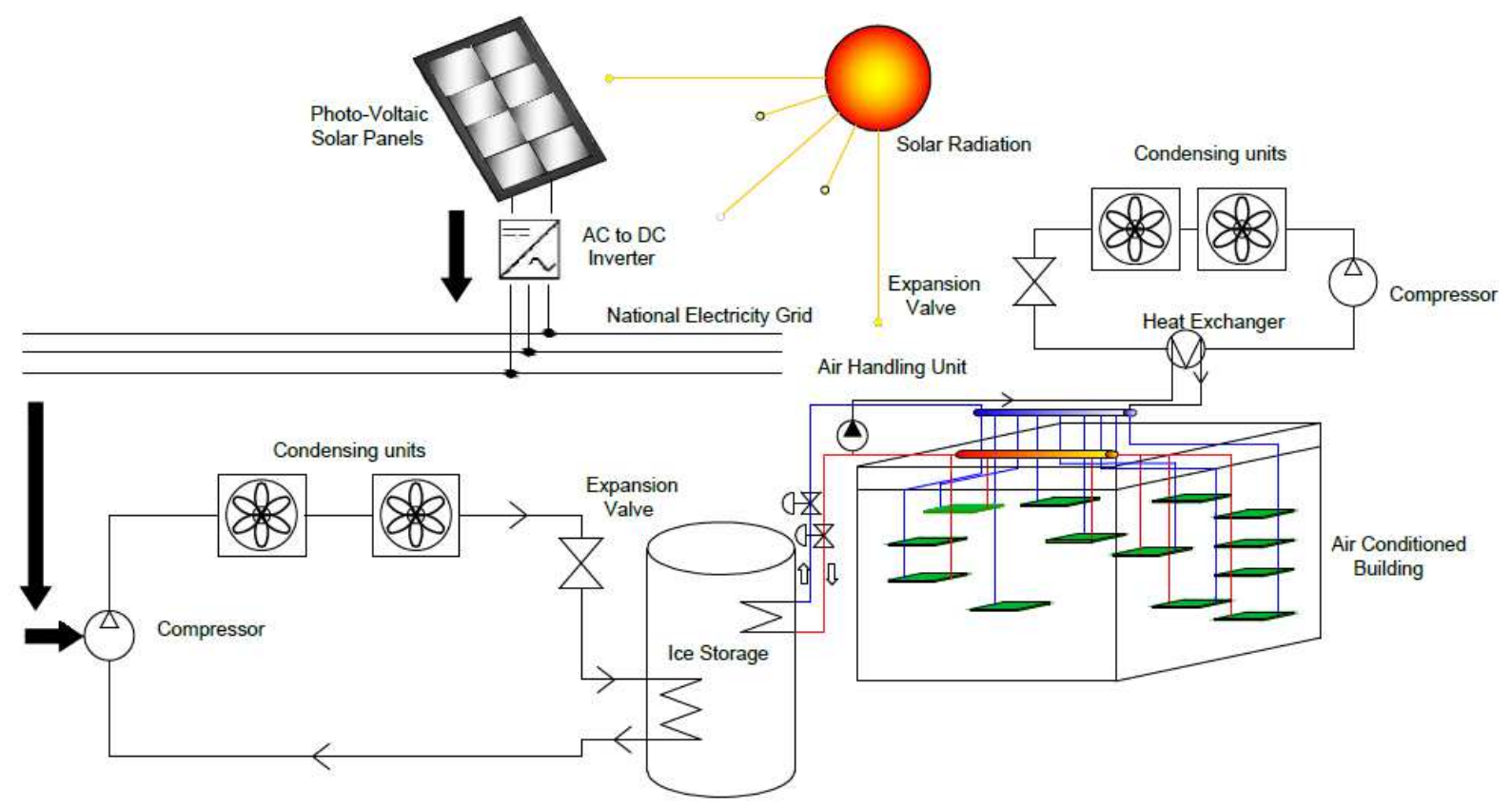

a) Proposed ice-storage all-water air conditioning system. 


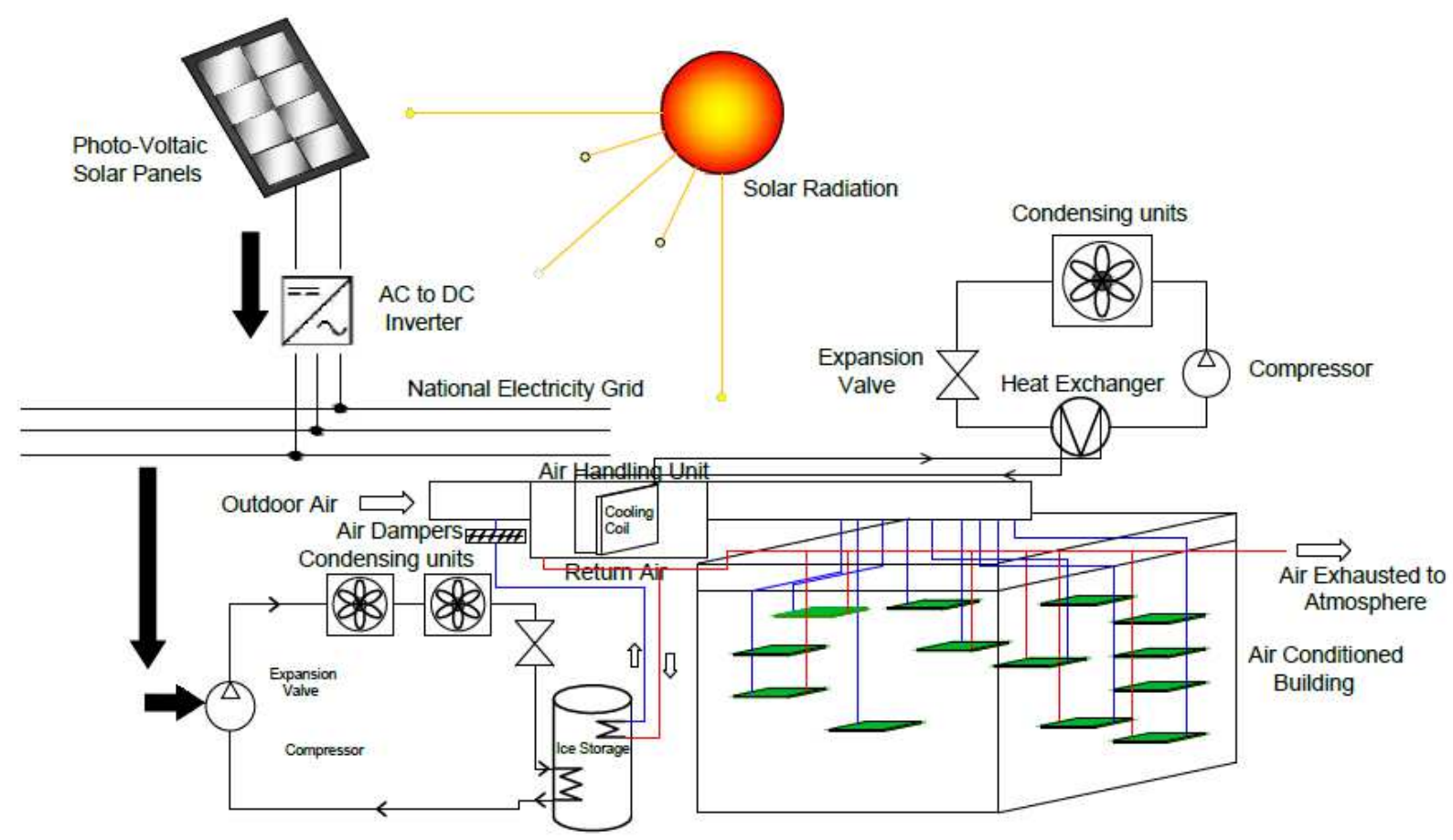

b) Proposed ice-storage all-air air conditioning system

Fig. 2. Proposed ice-storage air conditioning system.

The solar photo-voltaic model, the ice thermal storage model and the refrigeration cycle model are used to simulate the proposed system where mass and energy equations are developed in transient state. The charging and discharging periods for the system have been studied performing basic heat transfer analysis using the thermal ice storage model. The brine - the transport fluid- flows through small tubes where the ice is formed outside the tubes is assumed to have uniform growth. The heat transfer between adjacent tubes is assumed uniform as well. This can be defined into three main periods: (1) A sensible charging period: when the temperature of the tank decreases till reaching the freezing temperature. (2) An unconstrained latent charging period: which is the period when the ice is formed on the tubes with no intersection between ice formations on adjacent tubes, (3) A constrained latent charging period: when the ice formations join and the formation of ice reduces significantly due to the decrease in the heat transfer area. The temperature of ice starts to decrease more.

The energy balance for this period is presented by:

$$
Q_{b}+Q_{\text {gain }}=m_{w} C_{v, w} d T_{w} / d t-u_{i, f} d m_{i} / d t+m_{i} C_{v, i} d T_{i} / d t
$$

Where $Q_{\text {gain }}$ is the heat transfer rate from the ambient to the tank. 
During the discharge period, ice melts from the outer surface of tubes where relatively higher temperature brine flows through the tubes. Discharge periods are defined to (1) an unconstrained discharging period where water grows around the outer surface of the tubes. (2) Sensible and constrained discharging as soon as the water formations start intersecting where these periods are considered to be continuous at the point of transition. The governing equation for the discharged period can be expressed as:

$Q_{b}+Q_{\text {gain }}=m_{w} C_{v, w} d T_{w} / d t+u_{i, f} d m_{w} / d t$

The refrigeration cycle consists of four main devices: compressor, evaporator, condenser and expansion valve. Yuan and O'Neal (1994) studied the governing equations that present the operational performance of the refrigerant.

In this module, the solar radiation will be converted to electricity through a number of photo-voltaic cells. These cells will be connected in series arrangement. The power generated from this module can be presented as:

$$
P_{A C}=\eta_{\text {Inverter }} P_{D C}
$$

Where the DC output power of the photovoltaic module can be expressed using the temperature coefficient, the irradiance beam and the rated DC power $\left(P_{o}\right)$ estimated at the reference temperature $25^{\circ} \mathrm{C}$, as shown in Eq. 4:

$$
P_{D C}=0.001 P_{o} I_{a p}\left(1+\gamma_{t}\left(T_{c}-T_{r}\right)\right)
$$

A fraction index of 1.526 is substituted to find the transmittance through the glass in a standard single slab thin film module. Eq.5 presents the plane of array irradiance value in $\mathrm{W} / \mathrm{m}^{2}$.

$$
I_{a p}=I_{b e a m}+I_{s k}+I_{g r}
$$

Where $\left(I_{\text {beam }}\right)$ is the result of multiplying the solar irradiance beam value in the cosine of the incidence angle.

For the fixed solar panel, Eq.6 presents the angle of incidence for irradiance.

$$
\alpha_{i}=\cos ^{-1}\left(\cos \left(\gamma-\gamma_{s}\right) \sin (\beta) \sin \left(\theta_{s}\right)+\cos (\beta) \cos \left(\theta_{s}\right)\right)
$$

Energy Plus software (version 8.9.0) is used to simulate the photo-voltaic module. Generator and Inverter models are selected in this simulation. These two models included DC to AC conversion. A code is written to EnergyPlus (version 8.9.0) software in order to simulate the operation behaviour of the conventional and proposed system components for the two cities all around the year. 
For the new and conventional ice air conditioning systems, an exergy analysis has been performed to specify the total destruction in exergy occurring within the system.

The primary components present in the conventional systems of study are expansion valve, compressor, condenser and evaporator (AHU/FCU). The exergy destruction inside the compressor is calculated by performing exergy analysis to the system's cycles.

$$
\text { Exergy }_{\text {destroyed }, \text { comp }}=\dot{m}_{R}\left(h_{2}-h_{1}-T_{o}\left(s_{2}-s_{1}\right)\right)-P_{\text {comp }}
$$

The condenser's destruction in exergy is calculated using equation:

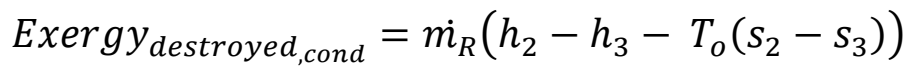

Also, the expansion valve exergy destruction can is defined from solving the following equation:

Exergy $_{\text {destroyed,exp }}=\dot{m}_{R}\left(T_{o}\left(s_{3}-s_{4}\right)\right)$

The evaporator exergy destruction of the studied Buildings is presented through the following equations respectively:

$$
\begin{aligned}
& \text { Exergy }_{\text {destroyed, }{ }_{\text {Ev }, \text { Admin. }}}=\dot{m}_{R}\left(h_{1}-h_{4}-T_{o}\left(s_{1}-s_{4}\right)\right)+\dot{m}_{w}\left(h_{6}-h_{5}-T_{o}\left(s_{6}-s_{5}\right)\right) \\
& \text { Exergy }_{d, \text { Ev,control }}=\dot{m}_{R}\left(h_{1}-h_{4}-T_{o}\left(s_{1}-s_{4}\right)\right)+\dot{m}_{\text {air }}\left(h_{A, e x}-h_{A, i n}-T_{o}\left(s_{A, e x}-s_{A, i n}\right)\right)
\end{aligned}
$$

The rate of exergy destruction for the ice storage and the heat exchanger tank based on the transient analysis are presented in the following equations respectively:

$$
\begin{aligned}
& \text { Exergy }_{\text {destroyed,ice tank }}=\int_{0}^{t}\left(1-T_{o} / T_{k_{\text {,ice }}}(t)\right) Q_{\text {ice }}(t) d t \\
& \text { Exergy }_{\text {destroyed }_{H E, i c e}}=\int_{0}^{t}\left(1-T_{o} / T_{k, H E}(\mathrm{t})\right) \mathrm{Q}_{\mathrm{HE}}(\mathrm{t}) d t
\end{aligned}
$$

While destruction in exergy of the compressor, the condenser and the expansion valve can be determined using the following equation respectively:

$$
\begin{aligned}
& \text { Exergy }_{\text {destroyed,comp,ice }}=\dot{m}_{R, \text { ice }}\left(h_{b}-h_{a}-T_{o}\left(s_{b}-s_{a}\right)\right)-P_{\text {Comp }, \text { ice }} \\
& \text { Exergy }_{\text {destroyed,cond,ice }}=\dot{m}_{R, i c e}\left(h_{b}-h_{c}-T_{o}\left(s_{b}-s_{c}\right)\right) \\
& \text { Exergy }_{\text {destroyed,exp,ice }}=\dot{m}_{R, \text { ice }}\left(T_{o}\left(s_{c}-s_{d}\right)\right)
\end{aligned}
$$

The exergy distraction in a thin film photovoltaic panel by calculated by using:

Exergy $_{\text {destroyed }_{P V}}=E x_{\text {in }}-E x_{\text {out }}$

Where $E x_{i n}$ represent the inlet exergy and can be calculated from Eq.18

$$
E x_{\text {in }}=I_{a p} A\left[1-(3 / 4)\left(T_{O} / T_{\text {sun }}\right)+(1 / 3)\left(T_{O} / T_{\text {sun }}\right)^{4}\right]
$$


While Ex $x_{\text {out }}$ is the outlet exergy and it is the subtract the PV thermal exergy from the PV electrical exergy

$E x_{\text {out }}=E x_{\text {electric }}+E x_{\text {thermal }}$

Ex $x_{\text {electric }}=$ Power $=I_{m} V_{m}$

$E x_{\text {thermal }}=U A\left[1-T_{O}-\left(T_{O}+T_{O}{ }^{2}\right) / T_{\text {cell }}\right]$

The overall heat transfer coefficient resembles a sum of the convection heat transfer coefficient and radiation heat transfer coefficient and can be found using the following equation:

$U=2.8+3.8 v+\varepsilon \delta\left(T_{s k}+T_{c e l l}\right)\left(T_{s k}^{2}+T_{c e l l}^{2}\right)$

And

$T_{s k}=\left[T_{O}{ }^{4}\left(1-0.261 \exp \left(-0.000777\left(T_{O}-273\right)^{2}\right]^{0.25}\right.\right.$

The total destruction in exergy for each cycle can be calculated from:

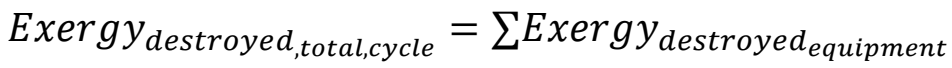

In addition, the thermal coefficient of the performance of the cycle can be defined using the following equation:

COP $P_{\text {cycle }}=\frac{Q_{\text {removed }}}{P_{\text {comp }}}$

While, the Second Law coefficient of performance of the cycle can be calculated from the following equation:

$\mathrm{COP}_{\text {exergy, }}{ }_{\text {cycle }}=\frac{Q_{\text {removed }}}{\left(P_{\text {comp }}+\text { Exergy }_{\text {destroyed }, \text { comp }}\right)}$

The former presented equations are solved numerically. The power saving, energetic COP, exergetic COP and the exergy destruction was calculated by using EES software version 9.430 where the transient heat transfer functions of EES software were implemented to perform the transient calculations related to the ice tank and the heat exchanger.

The code validation process was performed through the comparison between the outcomes and Yongfeng et al. [15] results for the ice weight change among the different time steps. The results presented a good agreement behaviour having maximum deviation of $6.6 \%$, as shown in Table 3 . 
Table 3: Comparison between the present code and Yongfeng et al. (2018).

\begin{tabular}{|c|c|c|c|}
\hline & \multicolumn{3}{|c|}{ Ice Weight (kg) } \\
\hline Time & Present Work & $\begin{array}{c}\text { Yongfeng et al. } \\
(\mathbf{2 0 1 8}) .\end{array}$ & Deviation (\%) \\
\hline $07: 20$ & 0 & 0 & 0 \\
\hline 08:05 & 8.5 & 7.8 & 8.24 \\
\hline 08:40 & 16 & 15.1 & 5.63 \\
\hline $09: 10$ & 21.7 & 20.1 & 7.37 \\
\hline $09: 45$ & 25.5 & 23.8 & 6.67 \\
\hline $10: 00$ & 27.5 & 26 & 5.45 \\
\hline $10: 20$ & 29.7 & 27.8 & 6.40 \\
\hline 11:05 & 32.5 & 30.5 & 6.15 \\
\hline $12: 05$ & 37.5 & 35.7 & 4.80 \\
\hline $13: 10$ & 40.4 & 38.6 & 4.46 \\
\hline $14: 10$ & 44.8 & 42.4 & 5.36 \\
\hline $15: 20$ & 47.8 & 45.9 & 3.97 \\
\hline $16: 10$ & 49.3 & 47 & 4.67 \\
\hline $17: 00$ & 52.5 & 49.7 & 5.33 \\
\hline
\end{tabular}

\section{Results and discussion}

The simulation performed for the proposed and conventional systems covered an entire year time, studied on an hourly basis. Fig.3. presents the amount of electric energy produced from solar PV panels. 


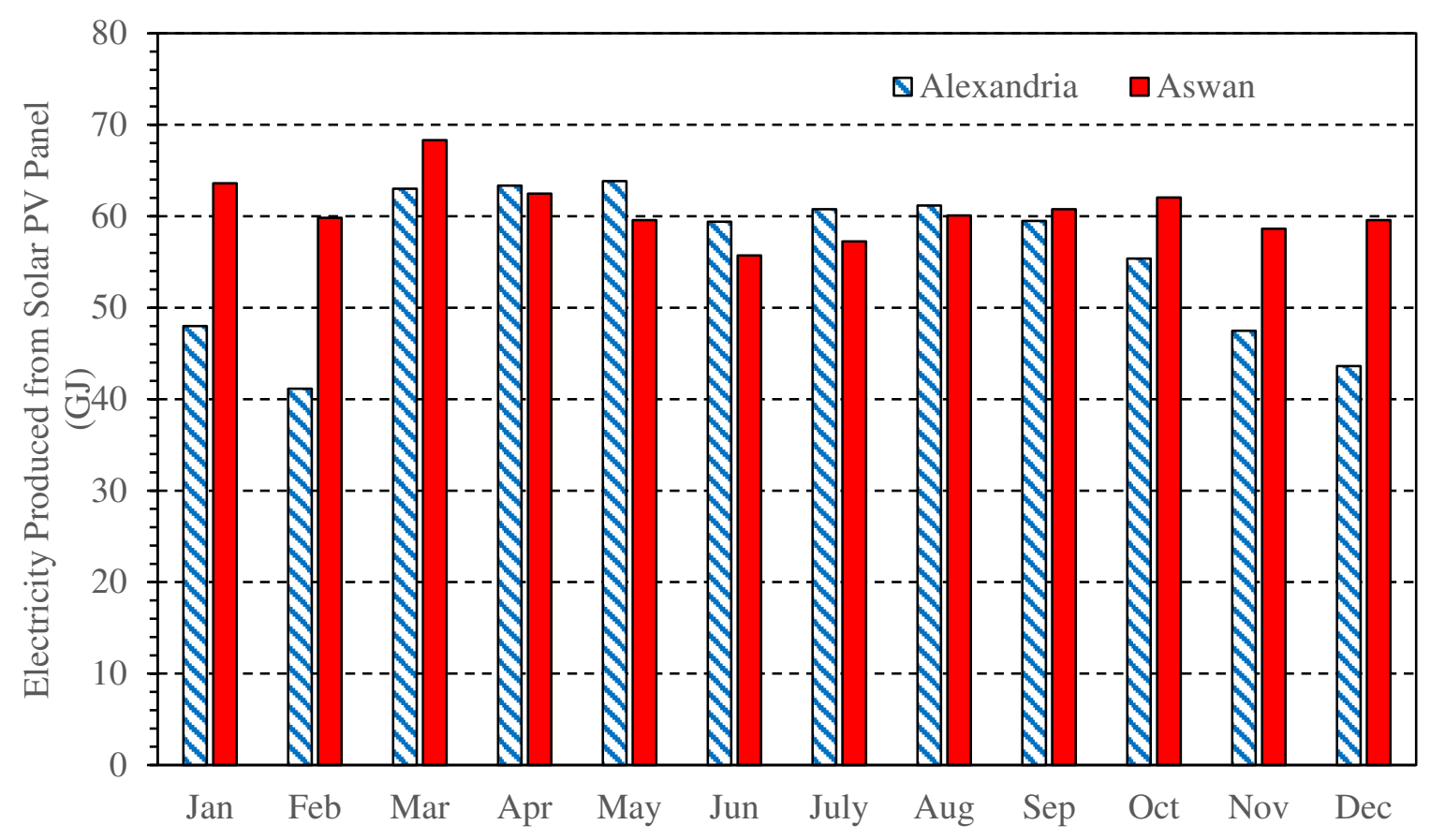

Fig. 3. Electric energy produced from PV panel, operating in the two cities.

Figs. 4 show the cumulative monthly electric energy bought for the old all-water system and the proposed system for each of the two studied cities. For Alexandria, the maximum electricity saved is 205.16 GJ, with a percent of $27.75 \%$, in August. In the meanwhile, the minimum amount of saving is $61.02 \mathrm{GJ}$, with a percent $90.7 \%$, in January. Although the maximum value of electricity generated from solar panels was in May as a result of maximum solar radiation, but the maximum energy saving occurred in August, because in May the air conditioning system operated under part load, which reduces the coefficient of performance. In case of Aswan, although the energy purchased each month is higher than Alexandria but the percent of energy saved reach 50.15\% in February as the electricity generated from the PV panels is almost covers half the air conditioner energy consumption. This happened as a result of higher solar radiation in this month which led to higher electricity generation. higher system coefficient of performance due to working under almost full load as the outside temperature is high. The maximum power saved is 224.67 GJ with percent $25.38 \%$ in August as a result of higher system coefficient of performance due to working under almost full load as the outside temperature is high. 


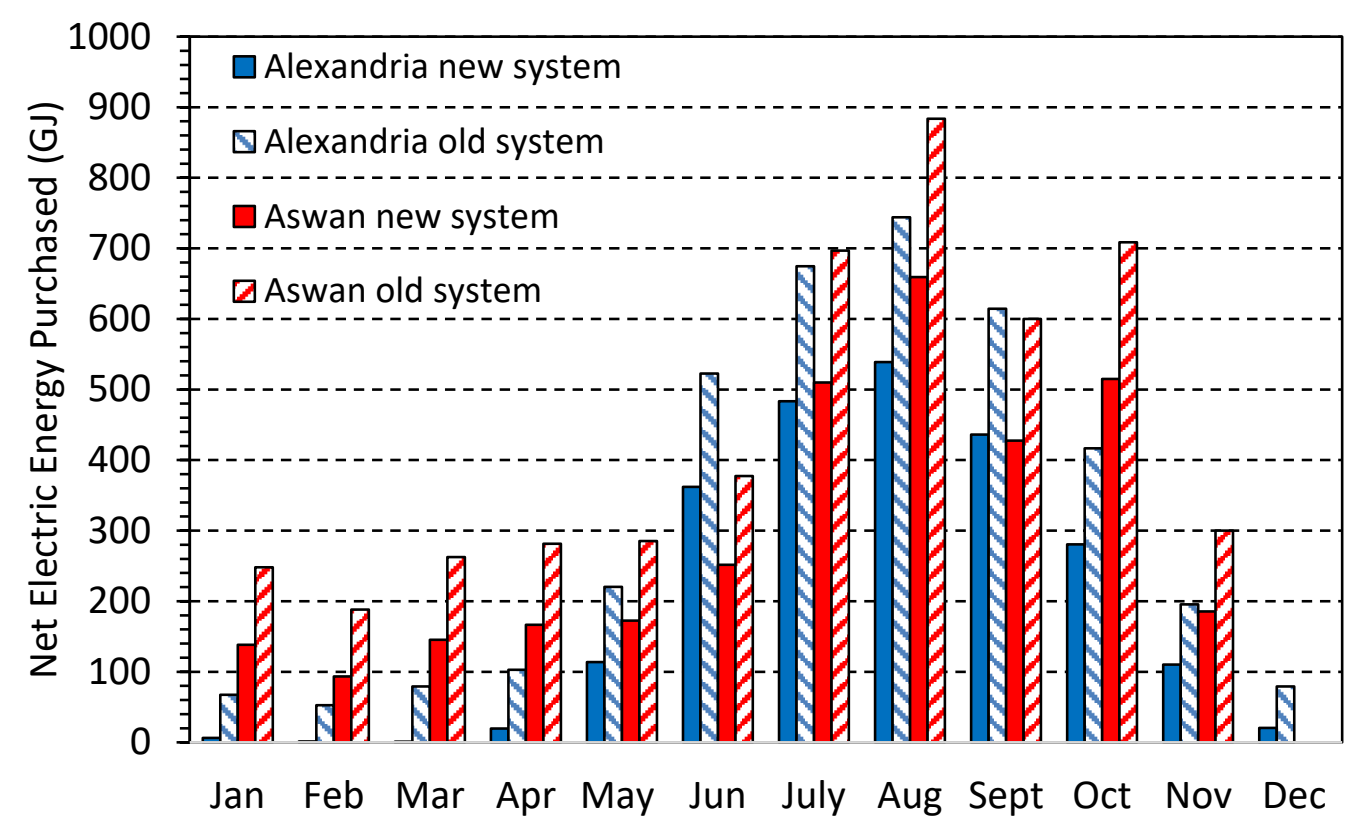

Fig. 4. Cumulated monthly electric energy purchased for conventional and proposed all-water systems for Alexandria and Aswan weather.

For all-air system, the electricity purchased from the national network for Alexandria and Aswan cities are shown in Fig. 5. For Alexandria city, the maximum energy saved is 175.05 GJ with 18.13\% saving percent in August. Also, the minimum energy saved is 57.93 GJ (69.1\% saving percent) in January. While in Aswan city, 175.45 GJ is saved in August with 17.43\% saving percent. As same as all-water system, $34.45 \%$ of the consumed power was saved in February as a result of increasing the coefficient of performance in winter and increasing the electricity produced from the PV panels.

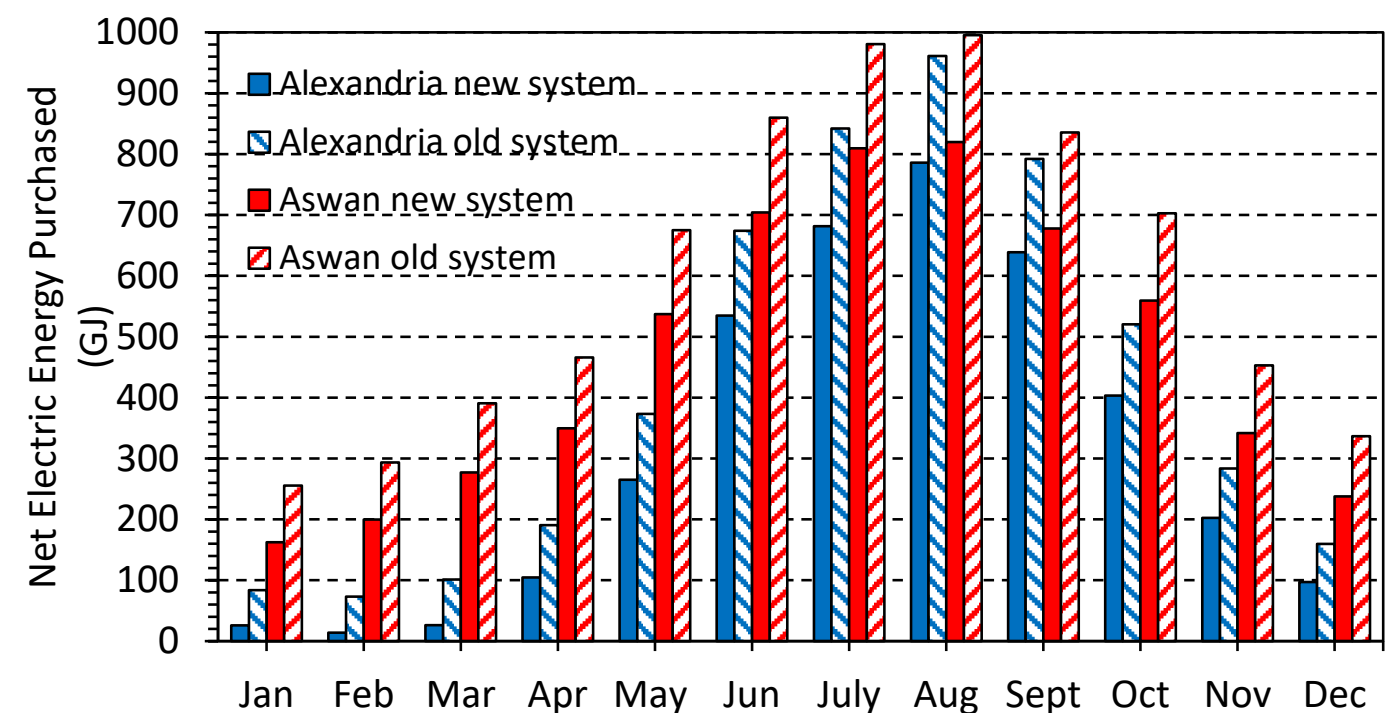

Fig. 5. Cumulated monthly electric energy purchased for conventional and proposed all-air systems for Alexandria and Aswan weather. 
An average exergic and energetic coefficient has been calculated for both conventional and proposed ice storage cycles to investigate the feasibility of using the ice storage system for hothumid and hot-dry climates as shown in Fig.6. For the all-water, the energetic coefficient of operation was raised from 2.915 to 3.589 when the solar-ice storage had been applied in Alexandria city. In addition, the exergetic coefficient of operation raised from 2.577 to 3.217. Also, in Aswan city, the proposed system increased the energetic and exergetic from 2.567, 2.165 to 3.468, 3.015 respectively. It is obvious from these data that the use of the proposed system in Aswan is more efficient than in Alexandria. This is due to that in Aswan the climate is dry so there is a big temperature variation between the day and the night. And as the ice produced in night so the coefficient of performance will increase in higher rate than in humid climate (Alexandria). Also, it can be observed that the increase in energetic and exergetic coefficients of performance in the allwater system is higher than in all-air system.

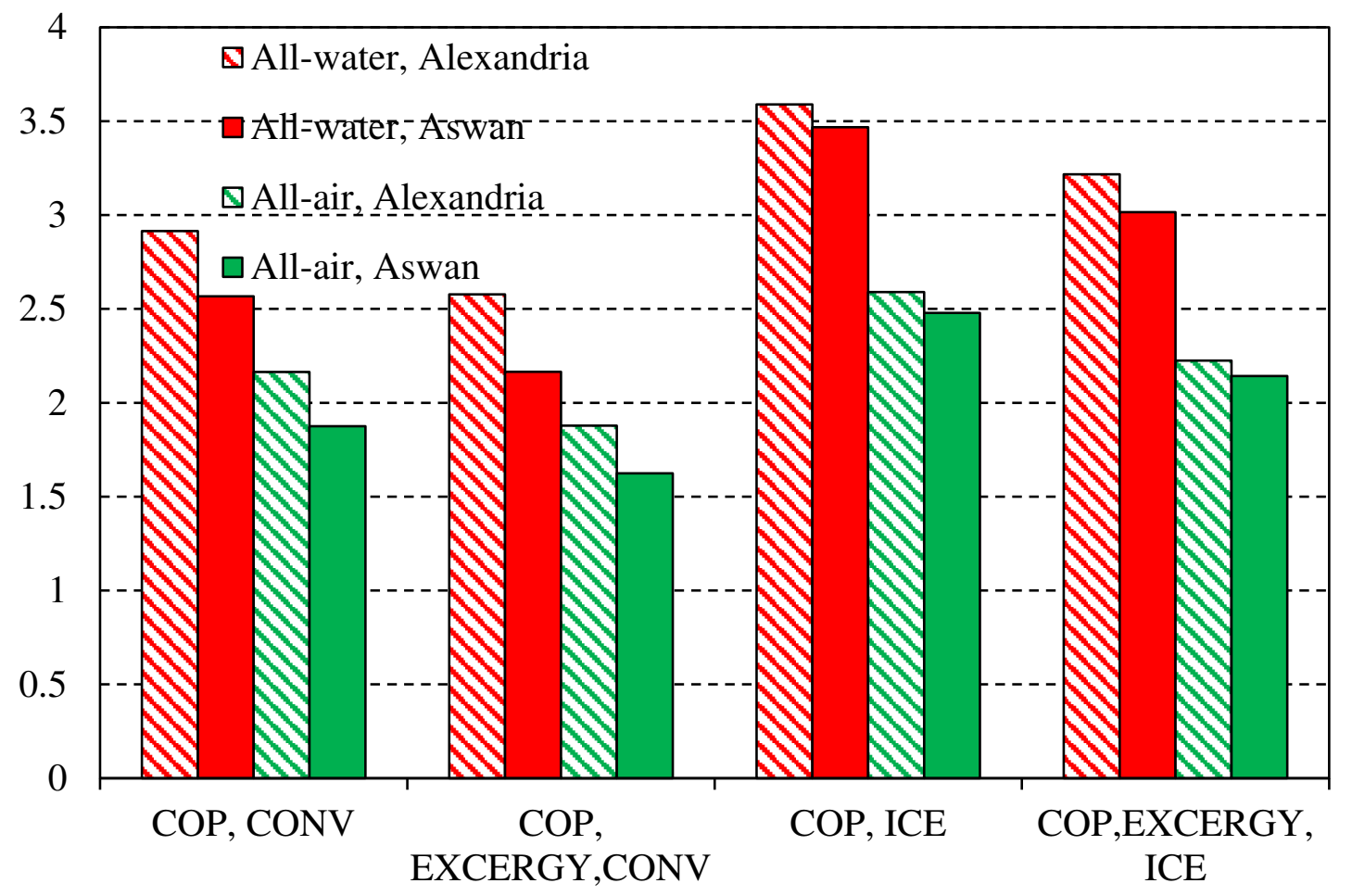

Fig.6. An average energetic and exergetic coefficient of performance.

The rate of exergy destruction within the ice tanks, PV module and heat exchangers during the discharging period in the two proposed systems located in Alexandria is shown in Fig. 7. The raised temperatures and reduced amount of heat rejection result in the decrease in exergy destruction rate. 
The exergy destruction rate of ice tanks decreases significantly at the start of the discharging period where the ice starts melting and the tank is filled with water of low temperatures. In the meanwhile, it is clearly visible from the figure that the exergy destruction in PV module will be maximum and nearly constant at the period from 13:40 until 14:20 as in this period the outside temperature is maximum. The same behaviour has been noticed for Aswan city but with different values.

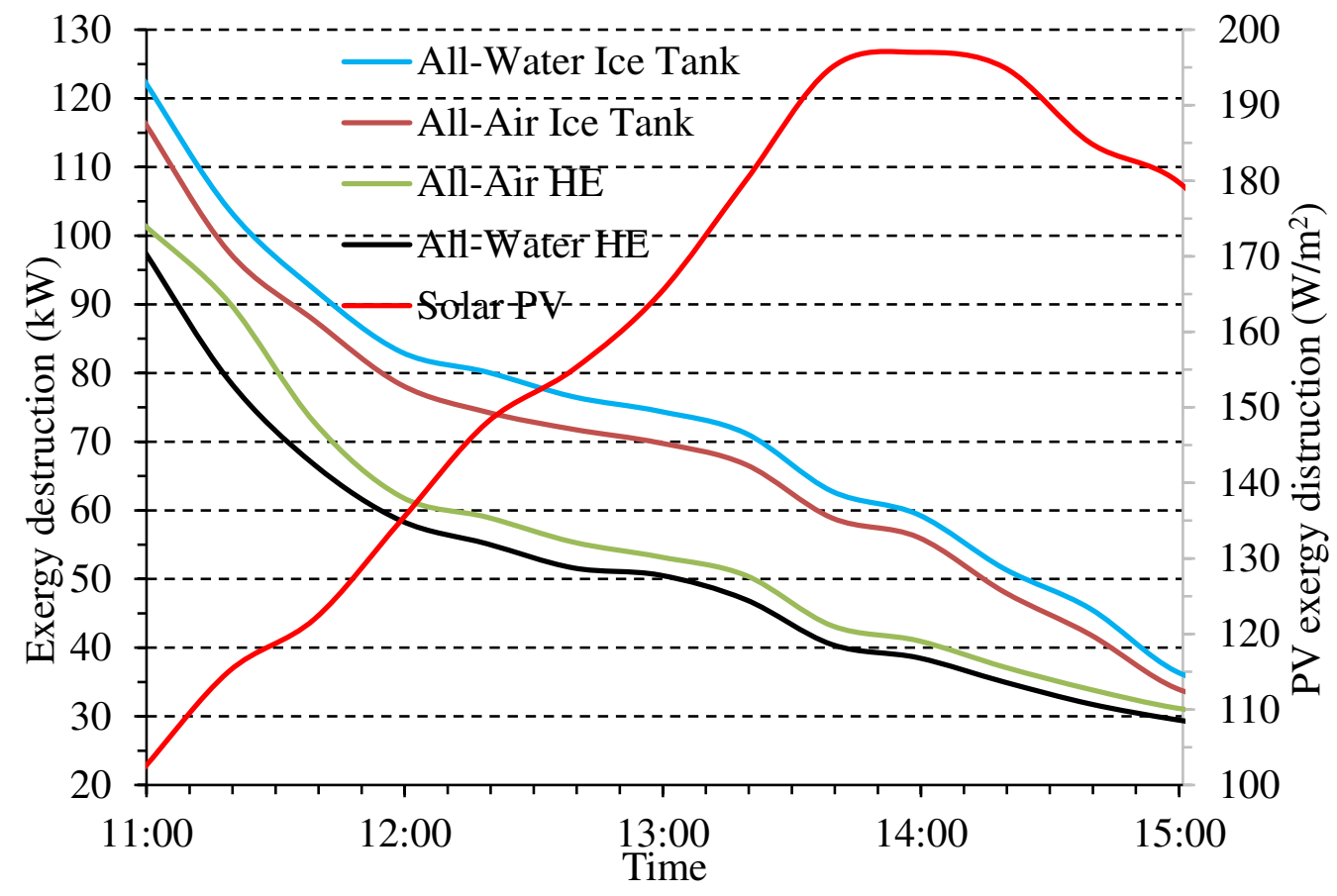

Fig.7. Exergy destruction rates of solar PV, ice tank and Heat exchanger on 22 August 2019 at Alexandria, Egypt.

Fig. 8 illustrates the net annual electric energy saved in case of the solar-ice storage system with air conditioning system. It is clear that the use of this proposed system with the all-water air conditioning system is more economical than its use with the all-air air conditioning system. For all-water system, the annual energy consumption reduced by $39.9 \%$ in the case of Aswan and $32.45 \%$ for Alexandria. On the other hand, the reduction in annual energy consumption for all- air system is $20.45 \%$ in case of Alexandria and $25.78 \%$ in the case of Aswan. Such significant electricity saving will impact on the operation cost as introduced in Table 4. The electric energy cost is taken 10 US cents/kWh. According to the Egyptian market prices, Table 5, the fixed cost for the suggested solar-ice storage all-water system is approximately 344994.7 USD and 348978 USD for all-air system. The cost difference between the proposed and the common all-water systems can be retrieved in 18 and 22 months for Aswan and Alexandria respectively. In the meanwhile, the allair systems difference can be retrieved in 24 and 30 months for Aswan and Alexandria respectively. 


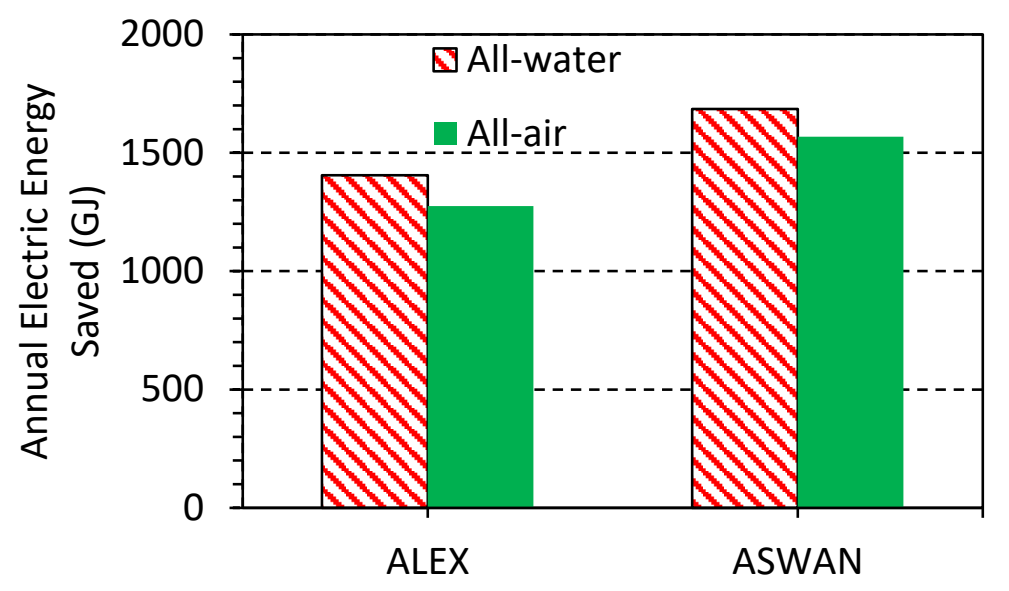

Fig.8. Annual electric energy saved.

Table 4: Annual money saving

\begin{tabular}{ccc}
\hline City & & Savings in US \$/yr. \\
\hline \multirow{2}{*}{ Alexandria } & All-water & 39081.62 \\
& All-air & 35786.18 \\
\hline \multirow{2}{*}{ Aswan } & All-water & 46790.54 \\
& All-air & 43545.89 \\
\hline
\end{tabular}

Table 5: Elements cost.

\begin{tabular}{lcccc}
\hline \multicolumn{4}{c}{ All-water } & \multicolumn{2}{c}{ All-air } \\
\hline & Old system & New system & Old system & $\begin{array}{c}\text { New } \\
\text { system }\end{array}$ \\
\hline Element & & & & \\
\hline Conventional system & 214853 & 166911.7 & 201742 & 170895.7 \\
\hline Ice storage cooling system & -- & 29411 & -- & 29411 \\
\hline Control system & 58823.5 & 72422 & 58823.5 & 72422 \\
\hline $\begin{array}{l}\text { Photovoltaic solar panel \& } \\
\text { Inverter }\end{array}$ & - & 76250 & -- & 76250 \\
\hline Total cost $(\$)$ & 273676.5 & 344994.7 & 260565.5 & 348978 \\
\hline
\end{tabular}

The environmental impact of the two proposed solar air-conditioning systems in reducing carbon dioxide $\left(\mathrm{CO}_{2}\right)$ emissions from electrical power generation was presented. The amount of $\mathrm{CO}_{2}$ emissions has been reduced despite obtaining the same required cooling capacities. The reduction 
in $\mathrm{CO}_{2}$ emissions is directly proportional to the achievement of fuel savings through the proposed solar air-conditioning systems with an ice storage system. As presented in Fig. 9, the amount of the decrease in $\mathrm{CO}_{2}$ emissions in hot-dry areas (Aswan) is greater than the amount of the decrease in hot-humid areas (Alexandria). The annual emissions were reduced by 467 tons for the city of Aswan, compared to 390 tons for the city of Alexandria when using the all-water air conditioning system. While in the case of using the all-air system, the annual reduction was 435 tons for Aswan and 353 tons for Alexandria. The results indicate that the all-water system is superior to the all-air system and that the proposed systems is better used in hot-dry areas than in hot-humid areas due to the fact that the electrical energy required was successfully reduced.

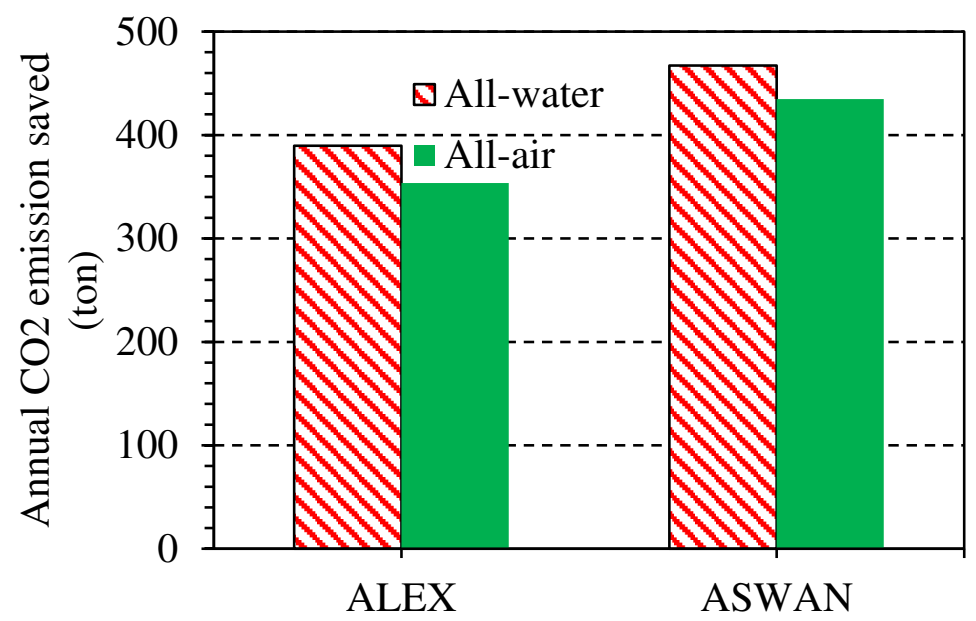

Fig.9. Annual $\mathrm{CO}_{2}$ emission saved.

\section{Conclusions}

The proposed air conditioning systems have shown an effective annual total electric energy reduction and notable money saving for the simulated climates through the following points:

- Both proposed systems showed notable energy savings compared to the original systems before modification.

- The all-water proposed system showed more overall energy savings compared to the proposed all-air system in both hot humid and hot dry climate.

- The use of solar-ice storage system is more efficient in hot humid climate than its use in hot dry climate. 
- From the exergy analysis, it can be noted that using solar-ice storage system increase the both conventional and exergy COP but this effect is more in case of hot-humid climate than hot-dry climate.

- For Alexandria city, all water proposed air conditioning system showed maximum electric energy saving of 205.16 GJ having a percentage $27.75 \%$ in August. The minimum amount of energy saved is 61.02 GJ having a percentage $90.7 \%$, in January.

- The study of the proposed all water system for Aswan's weather indicated 50.15\% energy saving in February where the electric energy generated from the PV panels approximately covers half the air conditioner energy consumption where August showed maximum amount of electricity saved estimated by 224.67 GJ having $25.38 \%$.

- In case of the proposed all air system, the maximum energy saved in case of Alexandria is estimated by 175.05 GJ having a percentage of $18.13 \%$ in August. while, the minimum amount of energy saved is 57.93 GJ having $69.1 \%$ in January.

- The study of the proposed all air system for Aswan's weather showed 175.45 GJ (17.43\%) energy saving in August. In February, the percentage of saved energy is $34.45 \%$.

- All- water system achieved the highest saved $\mathrm{CO}_{2}$ emission compared with all-air system. Also, the saved $\mathrm{CO}_{2}$ emission in hot-dry area is higher than the saved emission in hothumid area. The $\mathrm{CO}_{2}$ emission reduced by 390 tons/year and 467 tons/year in case of using all-water system in Alexandria and Aswan respectively. While, this reduction will be 353 tons/year and 435 tons/year in case of using all-air system for the same two cities respectively.

- The notable amount of solar energy naturally available for the two studied cities highlight that HVAC designers should consider integrating solar energy in all their future air conditioning system designs for the two cities Alexandria and Aswan.

\section{-Ethical Approval}

Approved

\section{-Consent to Participate}

Approved 


\section{-Consent to Publish}

Approved

\section{-Authors Contributions}

Mohamed ElHelw: Conceptualization, Methodology and results discussion.

Wael M. El-Maghlany and Mohamed Shawky Ismail: Results discussion and paper writing.

\section{-Funding}

No funding

\section{-Competing Interests}

The authors declare that they have no known competing financial interests or personal relationships that could have appeared to influence the work reported in this paper.

\section{- Availability of data and materials}

Not applicable

\section{References}

A. Fertelli, T. Yılmaz, O. Büyükalaca, Ice formation around a horizontal tube in a rectangular vessel, J. of Thermal Science and Technology, 2009. 29: p. 75-87.

A.R. Shaibani, M.M. Keshtkar, P. Talebizadeh Sardari, Thermo-economic analysis of a cold storage system in full and partial modes with two different scenarios: A case study, Journal of Energy Storage, 2019. 24: 100783.

B. A. Habeebullah, Economic feasibility of thermal energy storage systems: Application to Al-Haram Grand Holy Mosque air conditioning plant, JKAU: Eng. Sci, 2006. 16: p. 55-82. 
B. Rismanchi, R. Saidur, H.H. Masjuki, T.M.I. Mahlia, Thermodynamic evaluation of utilizing different ice thermal energy storage systems for cooling application in office buildings in Malaysia, Energy and Buildings, 2012. 53: p. 117-126.

B. Rismanchi, R. Saidur, H.H. Masjuki, TMI. Mahlia, Energetic, economic and environmental benefits of utilizing the ice thermal storage systems for office building applications, Energy and Buildings, 2012. 50: p. 347-354.

B. Yuehong, Z. Gaoli, Q. Lifeng, L. Hongyan, W. Hongyan, Study on the characteristics of charging/discharging processes in three-phase energy storage coupling in solar air conditioning system, Energy and Buildings. https://doi.org/10.1016/j.enbuild.2019.109456.

D. Carbonell, M. Battaglia, D. Philippen, M.Y. Haller, Numerical and experimental evaluation of ice storages with ice on capillary mat heat exchangers for solar-ice systems, International Journal of Refrigeration, 2018. 88: p. 383-401.

D. Feldman, M.M. Shapiro, Acids and their mixtures as phase-change materials for thermal energy storage, Solar Energy Materials, 1989. 18: p. 201-216.

D. MacPhee, I. Dincer, Performance assessment of some ice TES systems, International Journal of Thermal Sciences, 2009. 48: p. 2288-2299.

D. Rohde, T. Andresen, N. Nord, Analysis of an integrated heating and cooling system for a building complex with focus on long-term thermal storage, Applied Thermal Engineering, 2018. 145: p. 791-803.

F. Sehar, S. Rahman, M. Pipattanasomporn, Impacts of ice storage on electrical energy consumptions in office buildings, Energy and Buildings, 2012. 51: p. 255-262.

G. Fang, L. Xing, F. Yang, H. Li, Exergy analysis of a dual-mode refrigeration system for ice storage air conditioning, International Journal on Architectural Science, 2005. 6: p. 1-6.

H. Lin, X. Li, P. Cheng, B. Xu, Study on chilled energy storage of air-conditioning system with energy saving. Energy and Buildings, 2014. 79: p. 41-46. 
I. Dincer, M.A. Rosen, Exergy methods for assessing and comparing thermal storage systems, International Journal of Energy Research, 2003. 27: p. 415-430.

M.A. Rosen, R. Tang, I. Dincer, Effect of stratification on energy and exergy capacities in thermal storage systems, International Journal of Energy Research, 2004. 28; p. 177193.

M. Elhelw, A. ElHefni, Novel thermoelectric cell-enthalpy wheel air conditioning system integrated with solar panels, Solar Energy, 2018. 176: p. 526-534.

M.W. Jack, J. Wrobel, Thermodynamic optimization of a stratified thermal storage device, Applied Thermal Engineering, 2009. 29: p. 2344-2349.

S. Abo-Elfadl, M. Yousef, H. Hassan, Energy, exergy, and enviroeconomic assessment of double and single pass solar air heaters having a new design absorber, Process Safety and Environmental Protection, 2021. 149: p. 451-464.

S. Abo-Elfadl, M. Yousef, H. Hassan, Energy, exergy, economic and environmental assessment of using different passive condenser designs of solar distiller, Process Safety and Environmental Protection, 2021. 148: p. 302-312.

S. L. Chen, C. S. Jwo, B. S. Yang, J. Y. Yen, Theoretical and experimental Investigations of a packed ice-storage air conditioning system, J. of Chinese Society of Mechanical Engineers, 1997. 18: p. 445-456.

S. Sanaye, A. Shirazi, Thermo-economic optimization of an ice thermal energy storage system for air-conditioning applications, Energy and Buildings, 2013. 60: p. 100-109.

S. Talukdar, H.M.M. Afroz, M.A. Hossain, M.A. Aziz, M.M. Hossain, Heat transfer enhancement of charging and discharging of phase change materials and size optimization of a latent thermal energy storage system for solar cold storage application, Journal of Energy Storage, 2019. 24: 100797.

S. XiaoXia, W. Dong, The Research on the Load Prediction for Ice Storage System Based on Rough Set, International Journal of Smart Home, 2015. 9: p. 117-126. 
X. Song, T. Zhu, L. Liu, Z. Cao, Study on optimal ice storage capacity of ice thermal storage system and its influence factors, Energy Conversion and Management, 2018. 164: p. 288-300.

X. Yongfeng, L. Ming, L. Xi, M. Xun, W. Yunfeng, L. Guoliang, R.H.E. Hassanien, Experimental investigation of solar photovoltaic operated ice thermal storage airconditioning system, International Journal of Refrigeration, 2018. 86: p. 258-272.

X. Yuan, D. L. O'Neal, Development of a Transient Simulation Model of a Freezer Part I: Model Development, International Refrigeration and Air Conditioning Conference, 1994. Paper 250.

Y. Li, G. Zhang, G.Z. Lv, A.N. Zhang, R.Z. Wang, Performance study of a solar photovoltaic air conditioner in the hot summer and cold winter zone, Solar Energy, 2015. 117: p. 167-179.

Y.M. Han, R.Z. Wang, Y.J. Dai, Thermal stratification within the water tank, Renewable and Sustainable Energy Reviews, 2009. 13: p. 1014-1026.

Y. Xu, X. Ma, R.H.E. Hassanien, X. Luo, G. Li, M. Li, Performance analysis of static ice refrigeration air conditioning system driven by household distributed photovoltaic energy system, Solar Energy, 2017. 158: p. 147-160. 
Figures

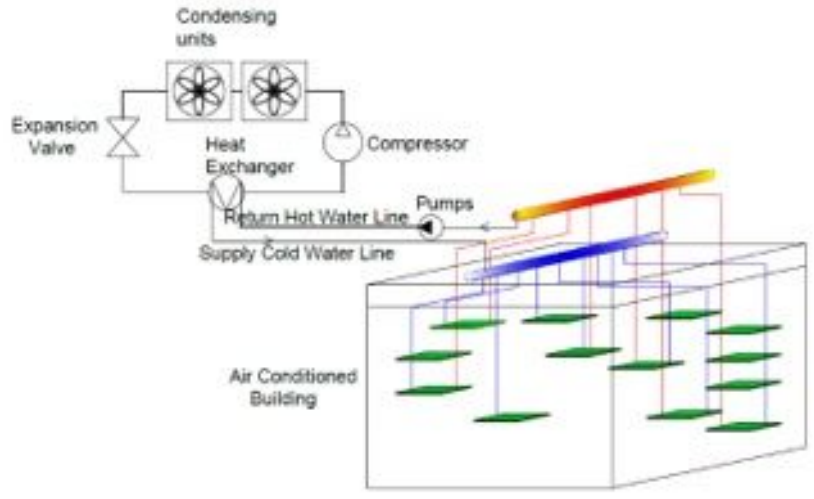

a) All-water air conditioning cycle

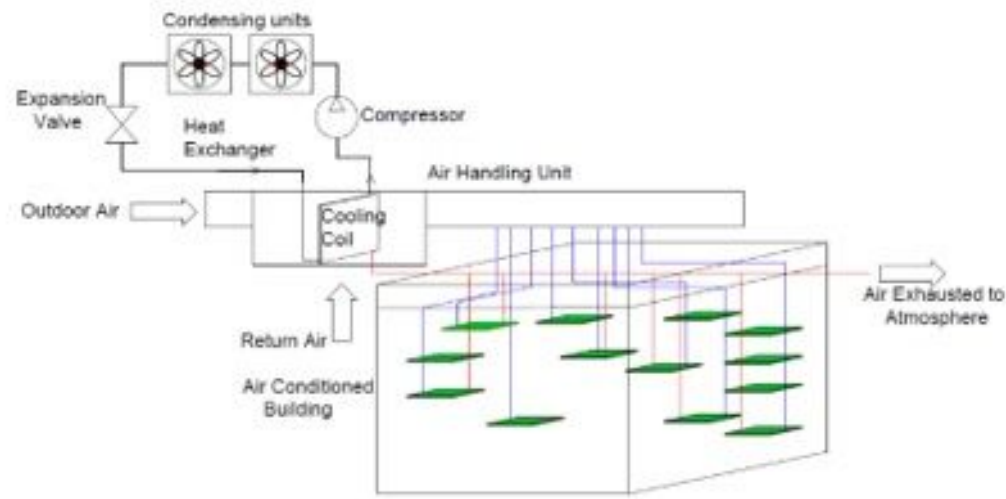

b) All-air air conditioning cycle

\section{Figure 1}

Conventional air conditioning cycles. 


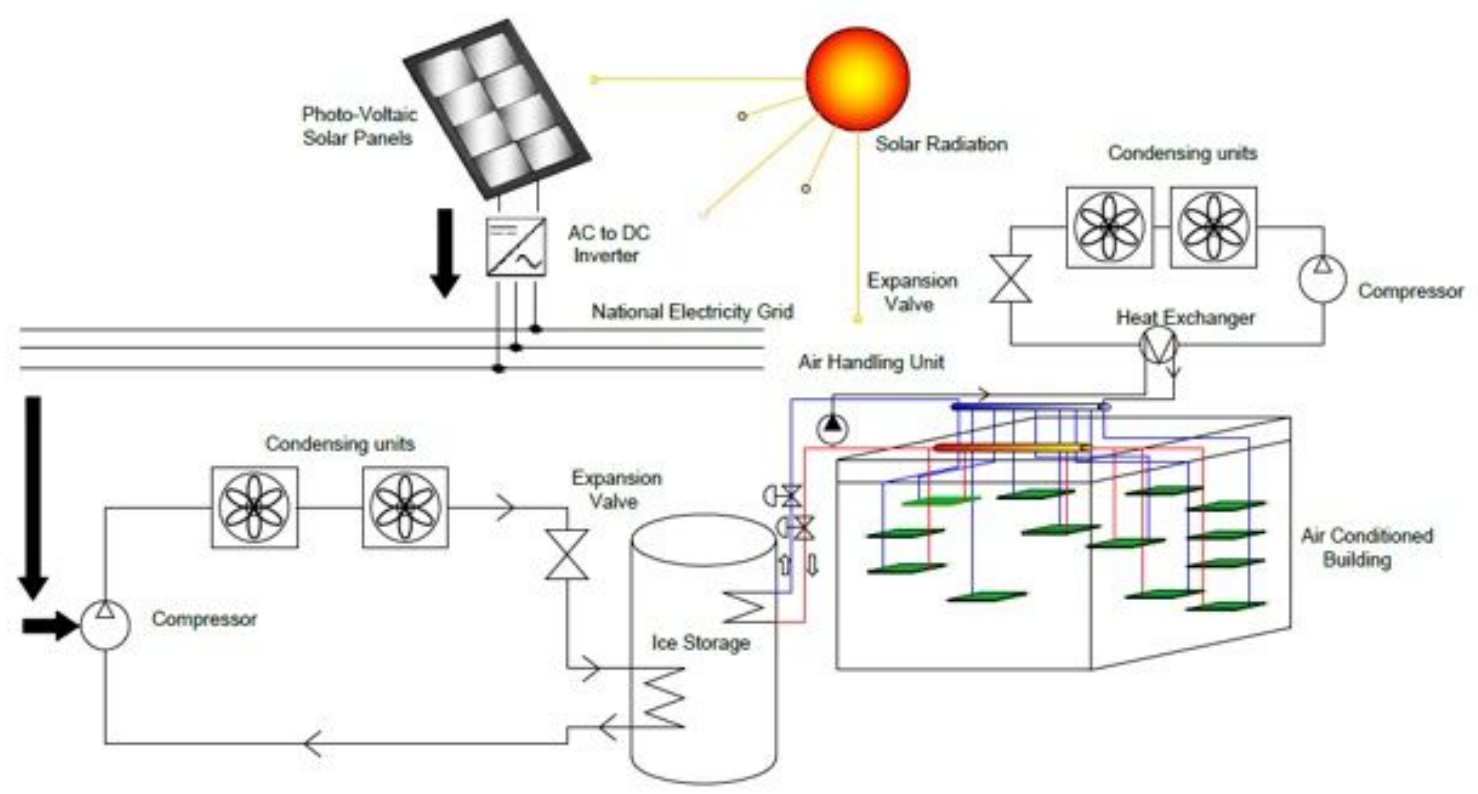

a) Proposed ice-storage all-water air conditioning system.

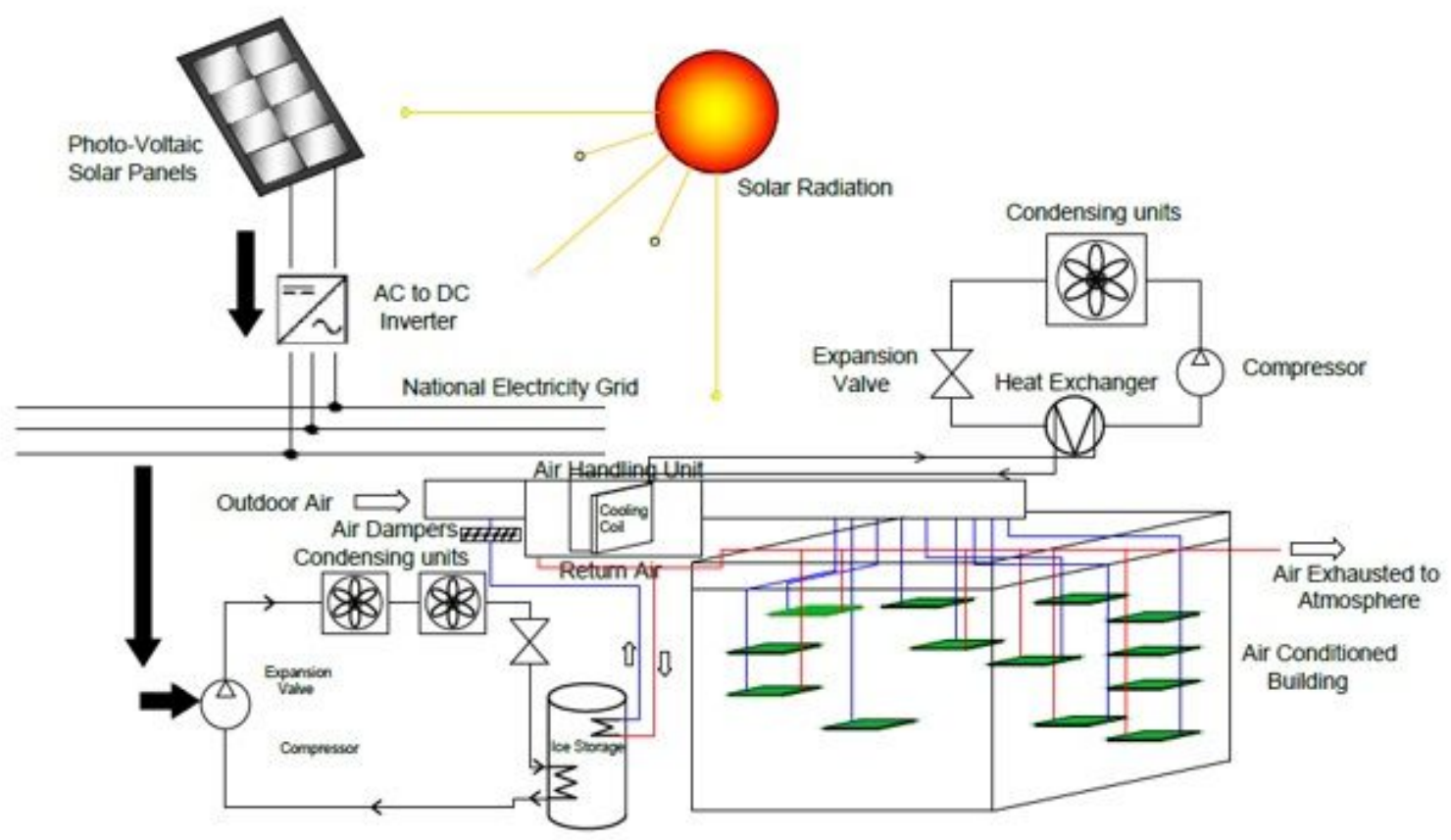

b) Proposed ice-storage all-air air conditioning system

\section{Figure 2}

Proposed ice-storage air conditioning system. 


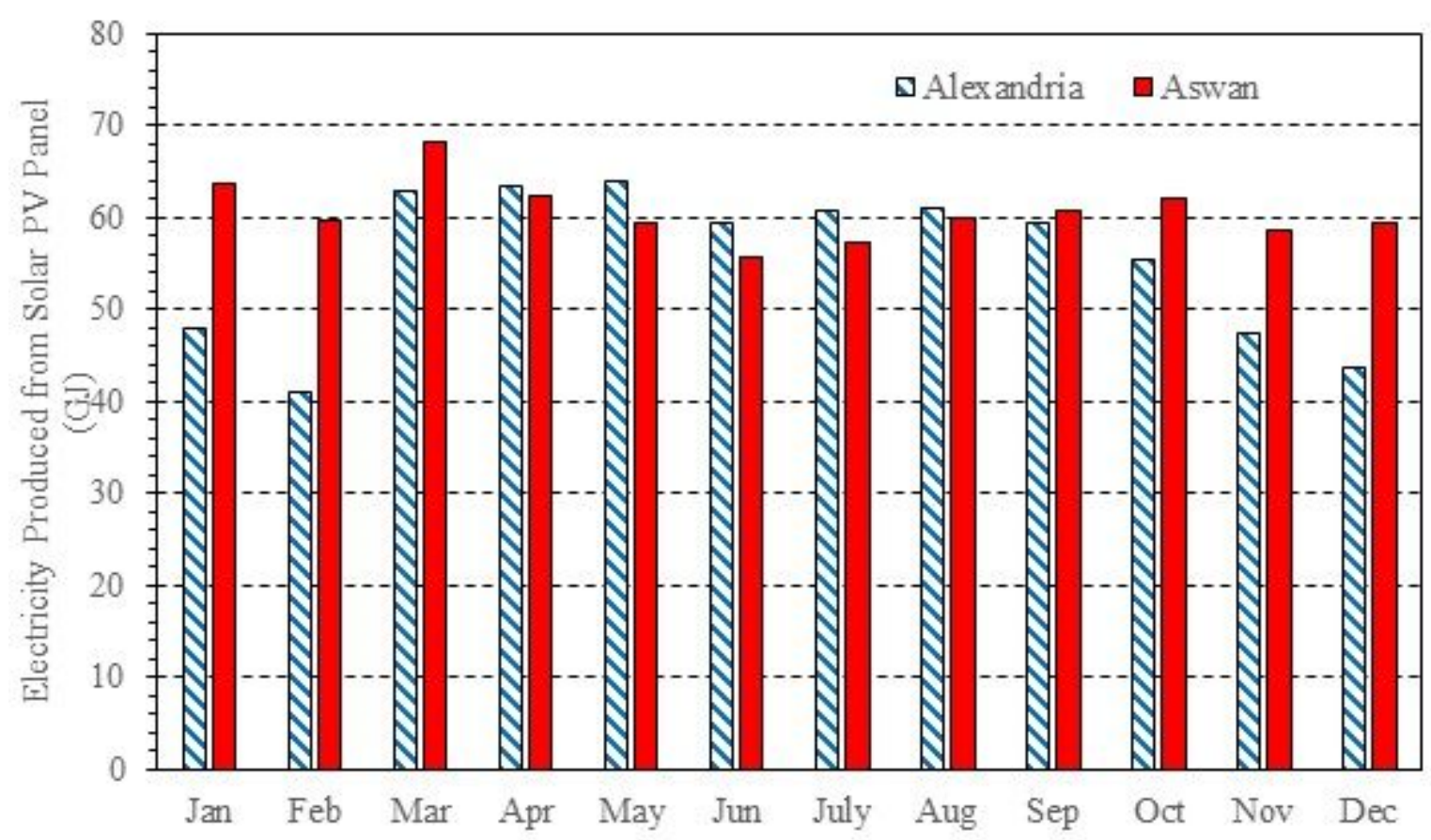

Figure 3

Electric energy produced from PV panel, operating in the two cities.

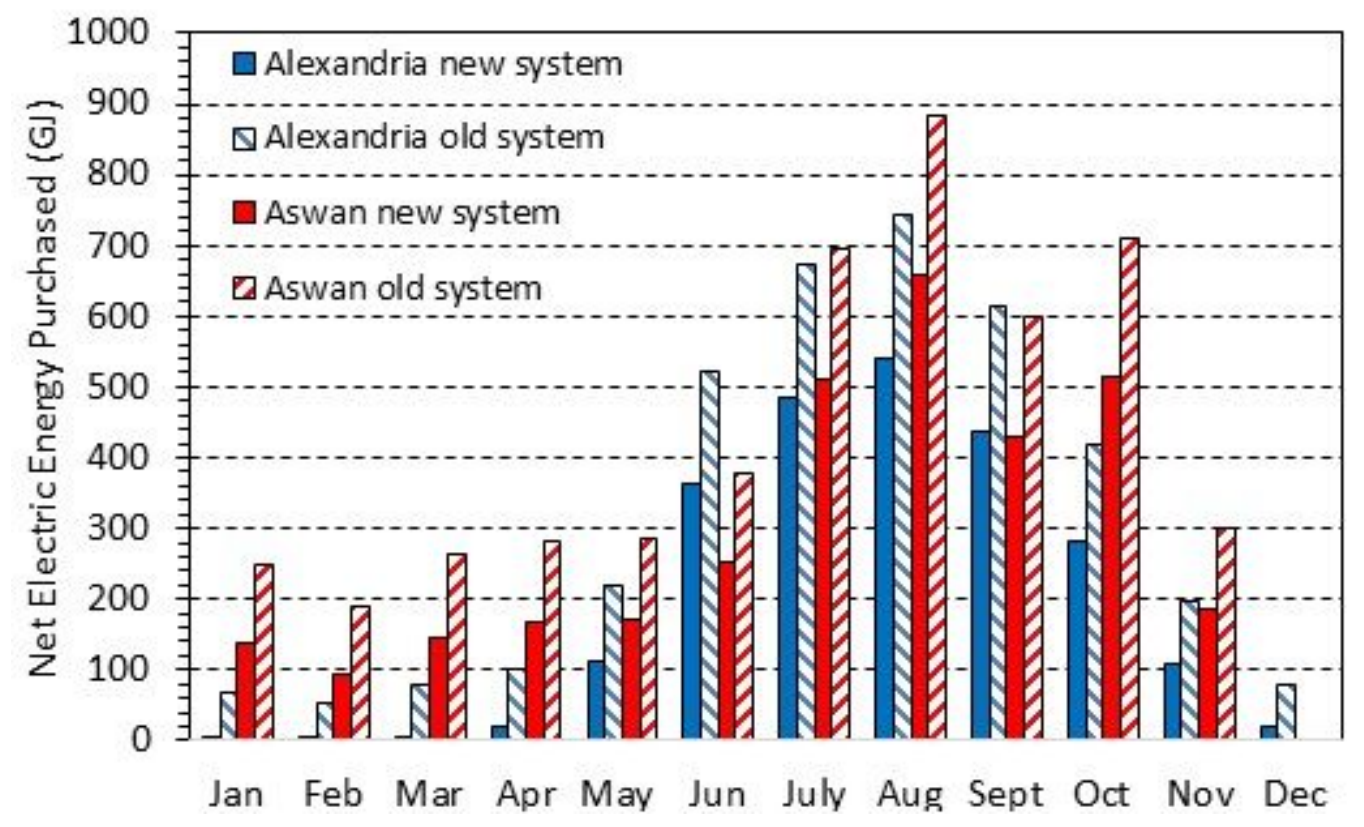

Figure 4

Cumulated monthly electric energy purchased for conventional and proposed all-water systems for Alexandria and Aswan weather. 


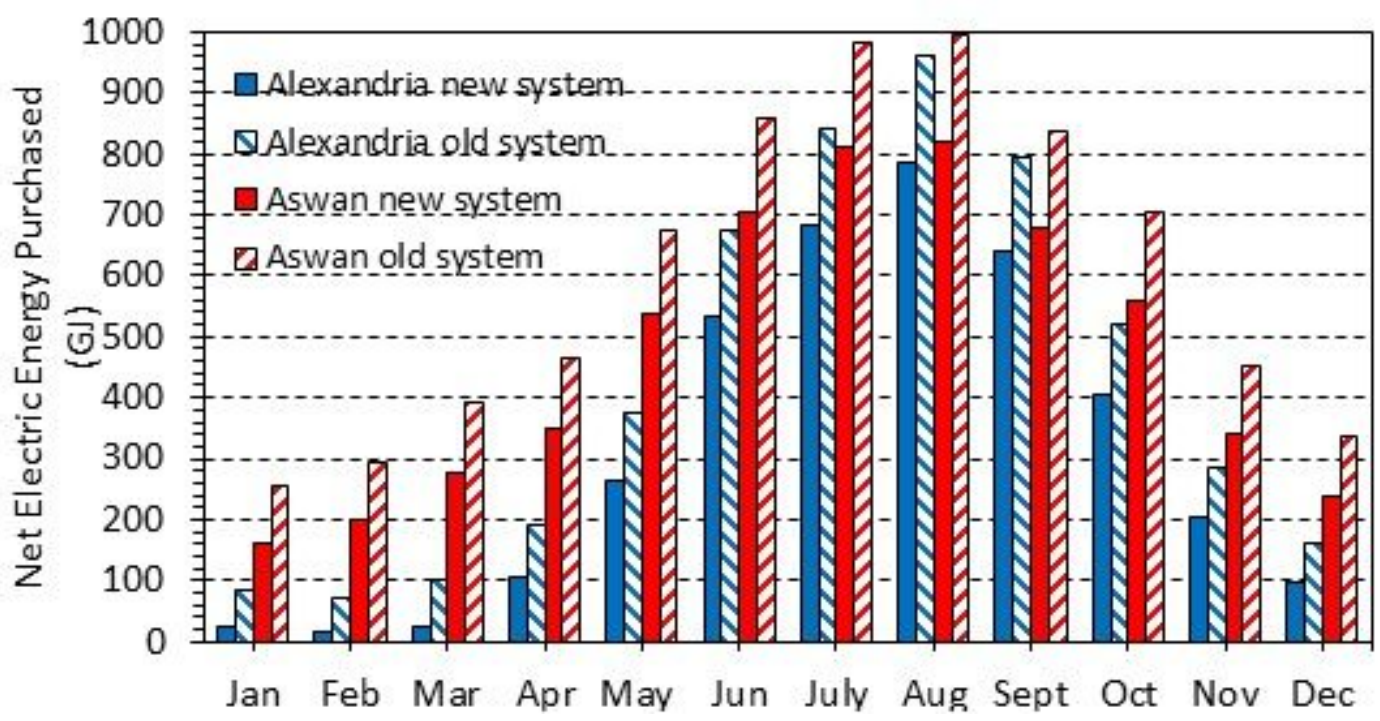

Figure 5

Cumulated monthly electric energy purchased for conventional and proposed all-air systems for Alexandria and Aswan weather.

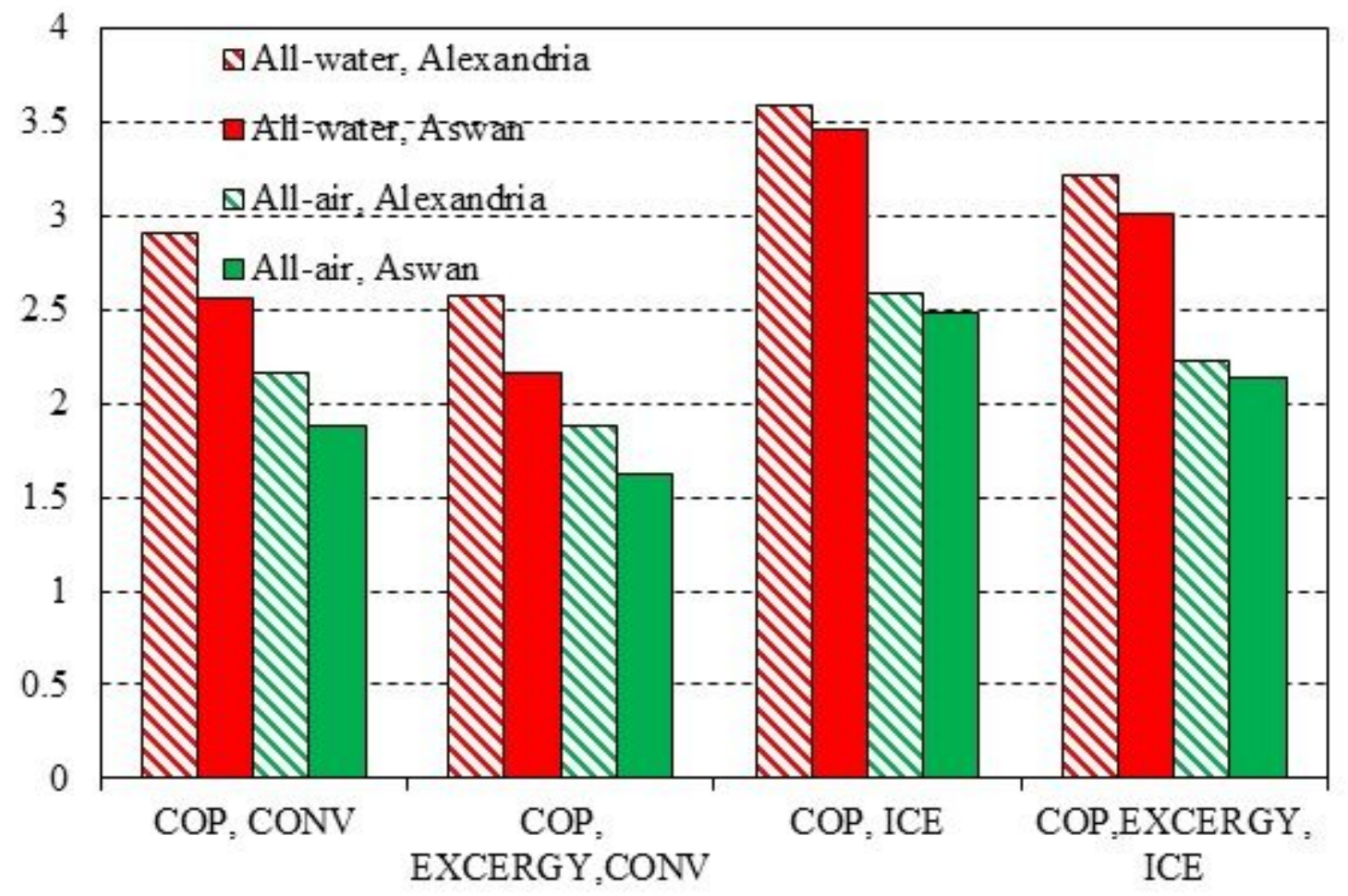

Figure 6

An average energetic and exergetic coefficient of performance. 


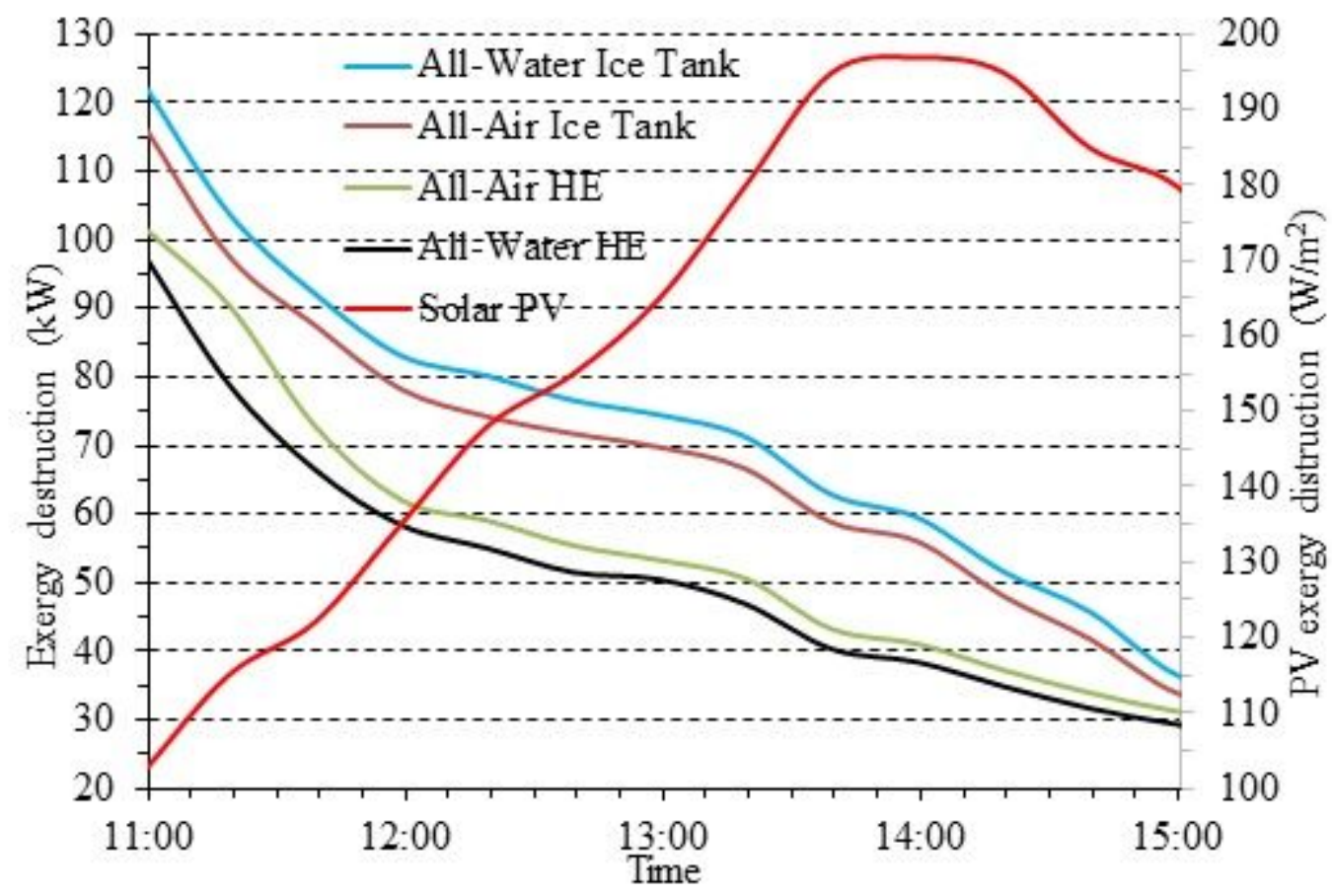

Figure 7

Exergy destruction rates of solar PV, ice tank and Heat exchanger on 22 August 2019 at Alexandria, Egypt.

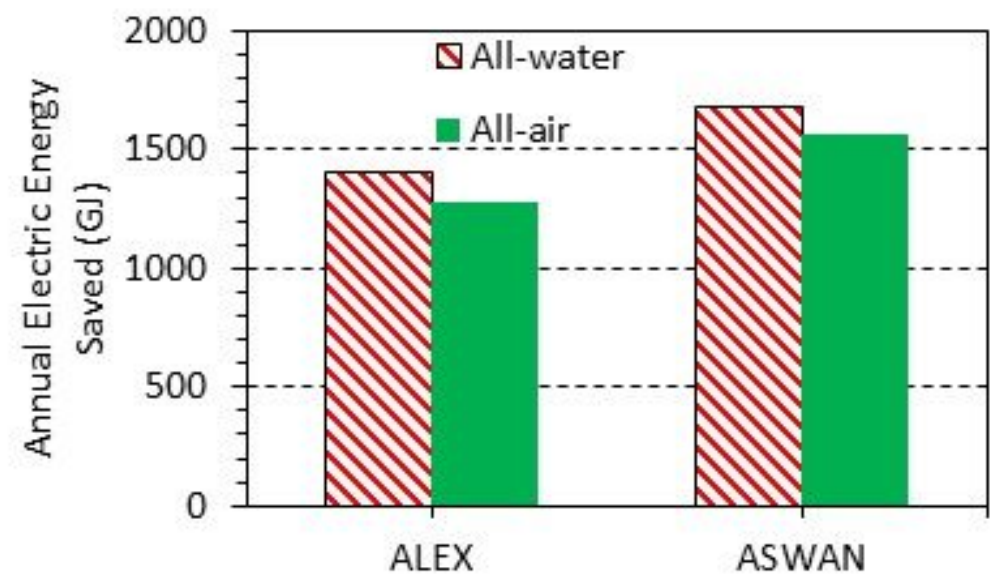

Figure 8

Annual electric energy saved. 


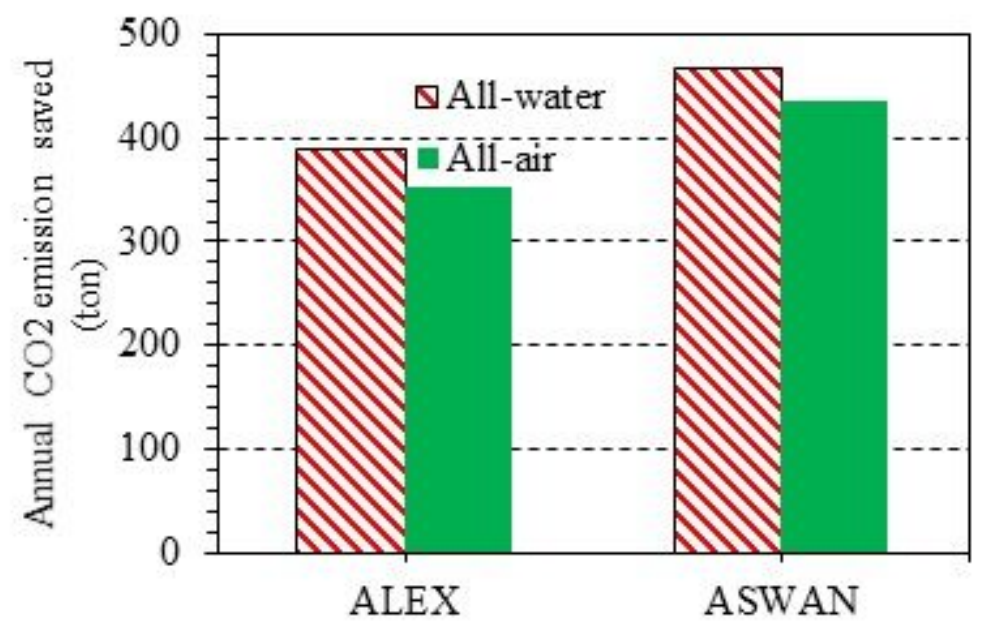

Figure 9

Annual CO2 emission saved. 